\title{
THE EFFECT OF DIFFERENT SHOE OUTSOLE SHAPE ON PLANTAR LOADING DISTRIBUTION DURING RUNNING IN CHINESE MALE UNDERGRADUATE STUDENTS
}

\author{
INFLUENTA TĂLPII EXTERIOARE DE DIFERITE FORME ASUPRA DISTRIBUTIEI PRESIUNII PLANTARE ÎN \\ TIMPUL ALERGĂRII LA STUDENTIII DE SEX MASCULIN DIN CHINA
}

\author{
Luming YANG ${ }^{1,2^{*}}$, Shuwen $\mathbf{W U}^{1}$ \\ ${ }^{1}$ National Engineering Laboratory for Clean Technology of Leather Manufacture, Chengdu, 610065, China, email: ylmll1982@126.com \\ ${ }^{2}$ Key Laboratory of Leather Chemistry and Engineering (Sichuan University), Chengdu, 610065, China
}

\begin{abstract}
THE EFFECT OF DIFFERENT SHOE OUTSOLE SHAPE ON PLANTAR LOADING DISTRIBUTION DURING RUNNING IN CHINESE MALE UNDERGRADUATE STUDENTS ABSTRACT. The purpose of this study was to examine the effect of different shoe outsole shapes on plantar loading distribution during running. Three pairs of shoes with different outsole shapes were selected, which were Skechers Go Run Ultra-C (shoe 1), Nike Free 5.0 (shoe 2) and Mizuno Wave Ascend 8 (shoe 3). The midfoot area of outsole in shoe 2 was flat while shoe 1 had a convex-shaped outsole, and the outsole of shoe 3 was concave in the midfoot area. We hypothesized that the three different shoe outsole shapes had a significant effect on the plantar pressure distribution, especially as the outsole shape changed from convex to concave the pressure presented an obvious increasing trend in the forefoot and rearfoot region. 20 healthy male recreational runners were recruited for this study. A Pedar-X inshoe pressure measure system (Novel GmbH, Munich, Germany) was used for data collection. Subjects were asked to wear each pair of shoes and ran at $2.2 \mathrm{~m} / \mathrm{s}$ on a treadmill. The order of test shoes was randomized. The data of right foot was collected for the statistical analysis and five foot strikes were averaged for each trail. The results of this study demonstrated significant differences in plantar loading distribution between the 3 different kinds of shoes, as the outsole shape changed from convex to concave the pressure presented an obvious increasing trend in the forefoot and rearfoot region.
\end{abstract}

KEYWORDS: running shoes, outsole, shape, plantar loading

\section{INFLUENTA TĂLPII EXTERIOARE DE DIFERITE FORME ASUPRA DISTRIBUTIEI PRESIUNII PLANTARE ÎN TIMPUL ALERGĂRII LA STUDENTII DE SEX} MASCULIN DIN CHINA

REZUMAT. Scopul acestui studiu a fost de a examina influenţa diferitelor forme ale tălpilor exterioare ale pantofilor asupra distribuţiei presiunii plantare în timpul alergării. S-au selectat trei perechi de pantofi cu tălpi de diferite forme, Skechers Go Run Ultra-C (model 1), Nike Free 5.0 (model 2) şi Mizuno Wave Ascend 8 (model 3). Zona mediană a tălpii la modelul 2 a fost plată, în timp ce modelul 1 a avut o talpă exterioară convexă, iar talpa modelului 3 a fost concavă în zona mediană. S-a emis ipoteza că cele trei forme diferite ale tălpilor au o influenţă semnificativă asupra distribuţiei presiunii plantare; mai ales la trecerea de la forma convexă a tălpii la cea concavă, presiunea a prezentat o tendinţă evidentă de creştere în regiunile antepiciorului şi retropiciorului. Pentru acest studiu s-au recrutat 20 de alergători sănătoşi de sex masculin. S-a utilizat sistemul de măsurare a presiunii cu branţuri Pedar-X (Novel GmbH, Munchen, Germania) pentru a colecta datele. Subiecţii au fost rugaţi să poarte fiecare pereche de pantofi şi să alerge cu viteza de $2,2 \mathrm{~m} / \mathrm{s}$ pe o bandă de alergare. Ordinea de testare a pantofilor a fost aleatorie. Datele preluate de la piciorului drept au fost utilizate pentru analiza statistică şi s-a făcut media a cinci atingeri ale solului cu piciorul pentru fiecare traseu. Rezultatele acestui studiu demonstrează diferenţe semnificative ale distribuţiei presiunii plantare între cele 3 tipuri diferite de pantofi, întrucât la trecerea de la talpa cu formă convexă la cea cu formă concavă, presiunea a prezentat o tendinţă evidentă de creştere în zonele antepiciorului şi retropiciorului.

CUVINTE CHEIE: pantofi de alergat, talpă exterioară, formă, presiune plantară

\section{L'EFFET DE DIFFÉRENTES FORMES DE SEMELLES EXTÉRIEURES SUR LA RÉPARTITION DE LA PRESSION PLANTAIRE LORS DE LA COURSE CHEZ LES ÉTUDIANTS CHINOIS DE SEXE MASCULIN}

RÉSUMÉ. Le but de cette étude a été d'examiner l'influence de diverses formes de semelles extérieures de chaussures sur la répartition de la pression plantaire pendant la course. On a choisi trois paires de chaussures à semelles de différentes formes, Skechers Go Run Ultra-C (modèle 1), Nike Free 5.0 (modèle 2) et Wave Mizuno Ascend 8 (modèle 3). Le médio-pied du modèle 2 était plat, tandis que le modèle 1 avait une semelle convexe et la semelle du modèle 3 était concave dans la région centrale. On a émis l'hypothèse que les trois différentes formes de semelles ont une influence notable sur la répartition de la pression plantaire; surtout en passant de la forme convexe de la semelle à la forme concave, la pression a montré une nette tendance à l'augmentation dans les régions de l'avant-pied et l'arrièrepied. Pour cette étude, on a recruté 20 coureurs de sexe masculin en bonne santé. On a utilisé le système de mesure de la pression Pedar-X (Novel GmbH, Munich, Allemagne) pour recueillir des données. On a demandé aux sujets de porter chaque paire de chaussures et de courir à la vitesse de $2,2 \mathrm{~m} / \mathrm{s}$ sur un tapis roulant. L'ordre de tester les chaussures a été aléatoire. Les données extraites du pied droit ont été utilisées pour l'analyse statistique et on a calculé la moyenne de cinq appuis du pied sur le sol pour chaque itinéraire. Les résultats de cette étude ont démontré des différences significatives dans la répartition de la pression plantaire entre les 3 types de chaussures différentes parce que à la transition de la semelle convexe à la semelle concave, la pression a montré une nette tendance à l'augmentation dans les régions de l'avant-pied et l'arrière-pied.

MOTSCLÉS: chaussures de course, semelle extérieure, forme, pression plantaire

*Correspondence to: Luming YANG, National Engineering Laboratory for Clean Technology of Leather Manufacture, Chengdu, 610065, China, Tel.: +86 186 2811 7800 , email:ylmII1982@126.com 


\section{INTRODUCTION}

Running is one of the most popular forms of exercise around the world. Many people run on a regular basis for exercise and many other kinds of sports include the motion of running such as football, basketball. With increased participation comes an increase in injury rates. Running injuries varies, a study by Taunton et al. found that the largest numbers of running injuries were reported in the knee $(42.1 \%)$, followed by the foot and ankle $(16.9 \%)$ and finally the lower leg (12.9\%) [1]. The most common injury types were muscle strains, ligament sprains and contusions [2]. And stress fractures were the most common overuse injuries, accounting for up to $50 \%$ of all injuries sustained by runners [3-6].

Risk factors of running injuries also vary and are fundamentally classified into two groups, extrinsic risk factors and intrinsic risk factors. Extrinsic risk factors include level of competition, skill level, shoe type, ankle bracing, playing surface, while intrinsic risk factors include age, sex, body size, foot type [7].

Plantar loading has also been reported related to running injuries [8, 9]. Playing surface, abnormal biomechanics, running shoes, foot type and strike patterns are also reported to influence plantar loading measurements [10-17]. Many researchers focused on the effect of running shoes. Dinato et al. found that running shoes with different cushioning properties would affect plantar loading and perception of comfort during running [18]. In another study, Ly et al. found that shoe midsole properties would influence plantar loading and impact force during running [19]. However, the differences in structures of running shoe outsole might also affect plantar loading.

There are proposed for this study three kinds of outsole shape in the off the shelf running shoe types. The main differences were in the midfoot area of the outsole, one was flat and the other two were separately convex and concave. Therefore, the purpose of this study was to examine the effect of different shoe outsole shape on plantar loading distribution during running. We hypothesized that the three different sole outsole shapes had a significant effect on the plantar pressure distribution, especially as the outsole shape

\section{INTRODUCERE}

Alergarea este una dintre cele mai populare forme de exerciţiu fizic din întreaga lume. Mulţi oameni aleargă în mod regulat pentru a se menţine fizic şi multe alte tipuri de sporturi includ acţiunea de alergare, cum ar fi fotbalul sau baschetul. 0 participare sporită atrage şi o creştere a numărului de accidente. Leziunile în urma alergării variază; un studiu efectuat de Taunton şi colab. a indicat că cel mai mare număr de leziuni au fost raportate la nivelul genunchiului $(42,1 \%)$, urmat de laba picioruluişigleznă (16,9\%), şi în cele de urmă, de gambe (12,9\%) [1]. Cele mai frecvente tipuri de leziuni au fost întinderile musculare, entorse şi contuzii ale ligamentelor [2]. Fracturile de stres au fost cele mai frecvente leziuni datorate suprasolicitării, reprezentând până la 50\% din leziunile totale suferite dealergători[3-6].

Factorii de risc ai leziunilor apărute în urma alergării variază, de asemenea, şi sunt clasificate în mod fundamental în două grupe, factorii de risc extrinseci şi factorii de risc intrinseci. Factorii de risc extrinseci includ nivelul de concurenţă, nivelul de calificare, tipul de pantof, rezistenţa gleznei, suprafaţa de joc, în timp ce factorii de risc intrinseci includ vârsta, sexul, dimensiunea corpului, tipul de picior [7].

Presiunea plantară a fost, de asemenea, raportată în corelaţie cu leziunile apărute în urma alergării $[8,9]$. Suprafaţa de joc, biomecanica anormală, pantofii de alergat, tipul de picior şi tiparul de mers influenţează, de asemenea, măsurătorile presiunii plantare [10-17]. Mulţi cercetători s-au concentrat asupra influenţei pantofilor de alergat. Dinato şi colab. au constatat că pantofii de alergat cu diferite proprietăţi de amortizare afectează presiunea plantară şi percepţia confortului în timpul alergării [18]. Într-un alt studiu, Ly şi colab. au constatat că proprietăţile tălpilor intermediare influenţează presiunea plantară şi forţa de impact în timpul alergării [19]. Cu toate acestea, diferenţele structurale ale tălpilor exterioare ale pantofilor de alergat pot, de asemenea, afecta presiunea plantară.

Sunt propuse pentru acest studiu trei tipuri de forme ale tălpilor exterioare din tipurile de pantofi de alergat disponibile în comerţ. Principalele diferenţe au fost localizate în zona centrală a tălpii exterioare, una fiind plată, una convexă, şi una concavă. Prin urmare, scopul acestui studiu a fost acela de a examina influenţa diferitelor forme ale tălpilor exterioare ale pantofilor asupra distribuţiei presiunii plantare în timpul alergării. S-a emis ipoteza că cele trei forme diferite ale tălpilor au o influenţă semnificativă asupra distribuţiei presiunii 
changed from convex to concave the pressure presented an obvious increasing trend in the forefoot and rearfoot region.

\section{METHODS}

\section{Subjects}

20 healthy male recreational runners were recruited for this study. All runners were rearfoot strikers with right-sided dominance. The basic information of subjects were presented in Table 1. All subjects had no history of lower extremity injuries in the past 6 months, no history of foot or ankle surgeries within the past 3 years and no history of stress fractures. They were physically active and ran at least 10 kilometers per week. Being physically active was operationally defined as participating in some kind of sports at least 3 times a week for approximately $1 \mathrm{~h}$ each time. Prior to participation each subject read and signed a consent form about the contents of the study. Ethical approval was obtained from the University Ethical Committee in accordance with the declaration of Helsinki. plantare; mai ales la trecerea de la forma convexă a tălpii la cea concavă, presiunea a prezentat o tendinţă evidentă de creştere în regiunile antepiciorului şi retropiciorului.

\section{METODE}

\section{Subiecţi}

Pentru acest studiu s-au recrutat 20 de alergători sănătoşi de sex masculin. Toţi alergătorii au atacat solul cu retropiciorul, predominant fiind piciorul drept. Informaţiile de bază ale subiecţilor au fost prezentate în Tabelul 1. Subiecţii nu au avut un istoric de leziuni în extremităţile inferioare în ultimele 6 luni, nu au avut intervenţii chirurgicale la picior sau gleznă în ultimii 3 ani şi nu au avut fracturi de stres. Au fost activi fizic şi au alergat cel puţin 10 kilometri pe săptămână. Activitatea fizică a fost definită ca participare la unele tipuri de sporturi de cel puţin 3 ori pe săptămână, timp de aproximativ 1 oră de fiecare dată. Înainte de a participa, fiecare subiect a citit şi a semnat un acord cu privire la conţinutul studiului. S-a obţinut aprobarea comitetului de etică al Universităţii, în conformitate cu Declaraţia de la Helsinki.

Table 1: Basic information of subjects (Mean value, Minimum value/Maximum value)

Tabelul 1: Datele subiecţilor (Valoare medie, valoare minimă/valoare maximă)

\begin{tabular}{c|c|c|c|}
$\begin{array}{c}\text { Foot Size } \\
\text { Măsură pantof }\end{array}$ & $\begin{array}{c}\text { Age (years) } \\
\text { Vârsta (ani) }\end{array}$ & $\begin{array}{c}\text { Weight }(\mathrm{kg}) \\
\text { Greutatea }(\mathrm{kg})\end{array}$ & $\begin{array}{c}\text { Height }(\mathrm{cm}) \\
\text { Inălţimea }(\mathrm{cm})\end{array}$ \\
\hline \hline 41 & $23(21 / 26)$ & $62.26(52.4 / 74.0)$ & $169.53(165 / 173)$ \\
\hline
\end{tabular}

\section{Data Collection}

A Pedar- $X$ in-shoe pressure measure system (Novel GmbH, Munich, Germany) was used to collect the plantar loading data. The Pedar measurement system has been proven to be an accurate, reliable, and repeatable measure of plantar loading [20-22].The Pedar insoles are approximately $2 \mathrm{~mm}$ thick and consist of 99 capacitive pressure sensors that are arranged in grid alignment. Prior to data collection, each insole pair was calibrated to 8 bar according to company specifications. After calibration, insoles which covered the entire plantar surface of the foot were placed bilaterally in one pair of shoes. The testing order was randomized for each subject in order to avoid any

\section{Colectarea datelor}

S-a utilizat sistemul de măsurare a presiunii cu branţuri Pedar-X (Novel GmbH, Munchen, Germania) pentru a colecta datele. Sistemul Pedar efectuează măsurători precise, fiabile şi repetabile ale presiunii plantare [20-22]. Branţurile Pedar sunt de aproximativ $2 \mathrm{~mm}$ grosime şi sunt formate din 99 de senzori capacitivi de presiune, cu dispunere de tip grilă. Înainte de colectarea datelor, fiecare pereche de branţuri a fost calibrată la 8 bari, conform specificaţiilor companiei. După calibrare, branţurile care acopereau întreaga suprafaţa plantară a piciorului au fost plasate bilateral într-o pereche de pantofi. Ordinea de testare a fost aleatorie pentru fiecare subiect pentru a evita apariţia 
fatigue effects. And they were blinded from the testing shoes during testing. Subjects were asked to wear each pair of shoes and ran at $2.2 \mathrm{~m} / \mathrm{s}$ on a treadmill. The data of right foot was used for the statistical analysis and five foot strikes were averaged for each trial. Subjects were allowed to familiarize themselves with the testing equipment and surrounding by walking or jogging on the treadmill for 3-5 min prior to testing.

\section{Shoes}

Three pairs of shoes with different outsole structures were selected, which were Skechers Go Run Ultra- C (shoe 1) (Figure 1A), Nike Free 5.0 (shoe 2) (Figure 1B) and Mizuno Wave Ascend 8 (shoe 3) (Figure 1C). The midfoot area of the outsole in shoe 1 was convex and its design philosophy was to adapt to the rearfoot striking patterns by make the swing process of foot easier. And the midfoot area of the outsole in shoe 2 was flat, while the outsole of shoe 3 was concave in the midfoot area. oboselii. Subiecţii nu au ştiut care au fost pantofii de testare în timpul derulării testelor. Aceştia au fost rugaţi să poarte fiecare pereche de pantofi şi să alerge cu viteza de $2,2 \mathrm{~m} / \mathrm{s}$ pe o bandă de alergare. Datele preluate de la piciorului drept au fost utilizate pentru analiza statistică şi $s$-a făcut media a cinci atingeri ale solului cu piciorul pentru fiecare proces. Subiecţilor li s-a permis să se familiarizeze cu echipamentele de testare şi cu mediul înconjurător prin mers sau jogging pe banda de alergare timp de 3-5 minute înainte de testare.

\section{Încălţăminte}

S-au selectat trei perechi de pantofi cu tălpi de diferite structuri, Skechers Go Run Ultra-C (model 1) (Figura 1A), Nike Free 5.0 (model 2) (Figura 1B) şi Mizuno Wave Ascend 8 (model 3) (Figura 1C). Zona mediană a tălpii la modelul 1 a fost convexă şi a fost proiectată pentru a se adapta la tiparele de atingere a solului cu retropiciorul prin facilitarea procesului de pendulare a piciorului. Zona mediană a tălpii la modelul 2 a fost plată, iar talpa modelului 3 a fost concavă în zona mediană.

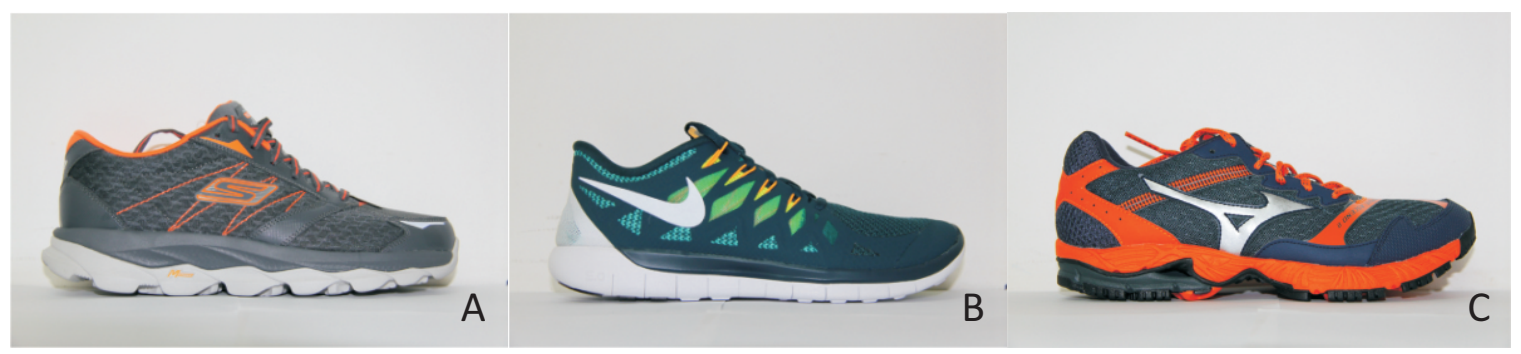

Figure 1. (A) Skechers Go Run Ultra-C (shoe 1); (B) Nike Free 5.0 (shoe 2); and (C) Mizuno Wave Ascend 8 (shoe 3) Figura 1. (A) Skechers Go Run Ultra-C (model 1); (B) Nike Free 5.0 (model 2); şi (C) Mizuno Wave Ascend 8 (model 3)

\section{Statistical Analysis}

Data was collected bilaterally; however, the right foot was used for the statistical analysis and five foot strikes were averaged for each trail. In order to analyze the in-shoe pressure data, the foot was divided into eight anatomic regions (rearfoot, medial midfoot, lateral midfoot, medial forefoot, middle forefoot, lateral forefoot, hallux and the lesser toes) using a percentage mask (Figure 2). The max force $(\mathrm{N})$ and the max pressure (kpa) were measured over the eight regions. Statistical analysis was performed using SPSS version 17.0 statistical analysis software. One- way ANOVA and LSD tests were used to examine if any

\section{Analiza statistică}

Datele au fost colectate bilateral; cu toate acestea, s-a utilizat piciorul drept pentru analiza statistică şi s-a făcut media a cinci atingeri ale solului cu piciorul pentru fiecare traseu. Pentru a analiza datele privind presiunea, piciorul a fost împărţit în opt regiuni anatomice (retropicior, zona centrală mediană, zona centrală laterală, antepiciorul median, antepiciorul central, antepiciorul lateral, halucele şi degetele), folosind o mască procentuală (Figura 2). S-au măsurat forţa maximă (N) şi presiunea maximă (kpa) în cele opt regiuni. Analiza statistică a fost realizată cu ajutorul programului de analiză statistică SPSS versiunea 17.0. S-au efectuat teste ANOVA cu un singur 
significant differences existed between the 3 shoe conditions. eşantion şi LSD pentru a examina dacă există diferenţe semnificativeîntre cele 3 modele de pantofi.

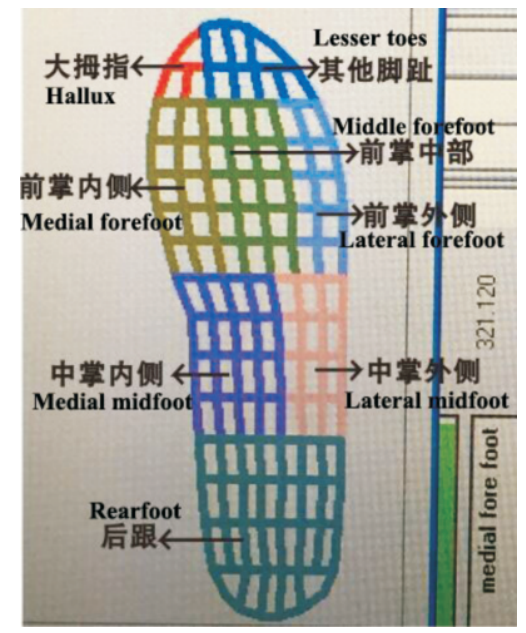

Figure 2. Anatomic division of plantar

Figura 2. Împărţirea amprentei plantare pe zone anatomice

\section{RESULTS}

\section{Plantar Loading Assessment}

When examining the results of max force difference, in rearfoot area, shoe 1 was significantly lower than shoe 3 ( $p=0.021)$. In medial midfoot area, shoe 1 was significantly higher than shoe $2(p=0.009)$ and shoe 3 ( $p<0.001)$, while shoe 2 was significantly higher than shoe $3(p=0.041)$. In lateral midfoot area, shoe 1 was significantly higher than shoe 3 ( $p=0.027)$. In the middle forefoot area, shoe 1 was significantly lower than shoe $3(p=0.041)$. Besides, in the rearfoot area, middle forefoot area and lateral forefoot area, the max force was increased gradually from shoe 1 to shoe 3 (Table 3).

When examining the results of max pressure difference, in medial midfoot area, shoe 1 was significantly higher than shoe $2(p=0.017)$. In middle forefoot area, shoe 1 was significantly lower than shoe $3(p=0.011)$. In addition, in the areas of rearfoot, medial forefoot, middle forefoot and lateral forefoot, the max pressure was increased gradually from shoe 1 to shoe 3 (Table 3).

\section{REZULTATE}

\section{Evaluarea presiunii plantare}

La examinarea rezultatelor diferenţelor de forţă maximă, în zona retropiciorului, modelul 1 a fost semnificativ mai mic decât modelul $3(p=0,021)$. În zona centrală mediană, modelul 1 a fost semnificativ mai mare decât modelul $2(p=0,009)$ şi modelul $3(p<0,001)$, în timp ce modelul 2 a fost semnificativ mai mare decât modelul 3 $(p=0,041)$. În zona centrală laterală, modelul 1 a fost semnificativ mai mare decât modelul 3 ( $p=0,027)$. În zona centrală a antepiciorului, modelul 1 a fost semnificativ mai mic decât modelul $3(p=0,041)$. În plus, în zona retropiciorului, zona centrală a antepiciorului şi zona antepiciorului lateral, forţa maximă a crescut treptat de la modelul 1 la modelul 3 (Tabelul 3).

La examinarea rezultatelor diferenţelor de presiune maximă, în zona centrală mediană, modelul 1 a fost semnificativ mai mare decât modelul 2 ( $p=0,017)$. În zona centrală a antepiciorului, modelul 1 a fost semnificativ mai mic decât modelul $3(p=0,011)$. În plus, în zona retropiciorului, zona antepiciorului median, zona antepiciorului central şi zona antepiciorului lateral, presiunea maximă a crescut treptat de la modelul 1 la modelul 3 (Tabelul 3 ). 
Table 2: Maximal force difference

Tabelul 2: Diferenţele de forţă maximă

\begin{tabular}{|c|c|c|c|}
\hline $\begin{array}{c}\text { Max force }(\mathrm{N}) \\
\text { Forţa maximă }(N)\end{array}$ & $\begin{array}{c}\text { Shoe 1 } \\
\text { Model 1 }\end{array}$ & $\begin{array}{c}\text { Shoe 2 } \\
\text { Model } 2\end{array}$ & $\begin{array}{c}\text { Shoe } 3 \\
\text { Model 3 }\end{array}$ \\
\hline $\begin{array}{c}\text { Rearfoot } \\
\text { Retropicior }\end{array}$ & $338.71 \pm 80.66^{\mathrm{b}}$ & $353.29 \pm 77.04$ & $419.91 \pm 0.01^{\mathrm{b}}$ \\
\hline $\begin{array}{c}\text { Medial midfoot } \\
\text { Zona centrală mediană }\end{array}$ & $225.55 \pm 31.90^{\mathrm{ab}}$ & $192.60 \pm 29.53^{\mathrm{ac}}$ & $167.12 \pm 39.37^{\mathrm{bc}}$ \\
\hline $\begin{array}{c}\text { Lateral midfoot } \\
\text { Zona centrală laterală }\end{array}$ & $207.21 \pm 32.12^{\mathrm{b}}$ & $203.35 \pm 41.13$ & $175.81 \pm 36.17^{\mathrm{b}}$ \\
\hline $\begin{array}{c}\text { Medial forefoot } \\
\text { Antepicior median }\end{array}$ & $221.44 \pm 60.20$ & $249.01 \pm 67.70$ & $241.73 \pm 79.84$ \\
\hline $\begin{array}{c}\text { Middle forefoot } \\
\text { Antepicior central }\end{array}$ & $305.12 \pm 62.90^{\mathrm{b}}$ & $328.66 \pm 68.61$ & $349.62 \pm 64.93^{\mathrm{b}}$ \\
\hline $\begin{array}{c}\text { Lateral forefoot } \\
\text { Antepicior lateral }\end{array}$ & $162.63 \pm 47.55$ & $166.88 \pm 44.67$ & $176.50 \pm 40.58$ \\
\hline $\begin{array}{c}\text { Hallux } \\
\text { Haluce }\end{array}$ & $59.59 \pm 19.73$ & $73.12 \pm 30.73$ & $72.64 \pm 31.54$ \\
\hline $\begin{array}{c}\text { Lesser toes } \\
\text { Degete }\end{array}$ & $92.82 \pm 27.28$ & $83.80 \pm 27.10$ & $87.82 \pm 31.30$ \\
\hline
\end{tabular}

Table 3: Maximal pressure difference

Tabelul 3: Diferenţele de presiune maximă

\begin{tabular}{|c|c|c|c|}
\hline $\begin{array}{c}\text { Max Pressure (kPa) } \\
\text { Presiune maximă }(\mathrm{kPa})\end{array}$ & $\begin{array}{c}\text { Shoe 1 } \\
\text { Model 1 }\end{array}$ & $\begin{array}{c}\text { Shoe 2 } \\
\text { Model } 2\end{array}$ & $\begin{array}{c}\text { Shoe 3 } \\
\text { Model 3 }\end{array}$ \\
\hline $\begin{array}{c}\text { Rearfoot } \\
\text { Retropicior }\end{array}$ & $179.17 \pm 49.12$ & $184.02 \pm 55.07$ & $224.79 \pm 107.31$ \\
\hline $\begin{array}{c}\text { Medial midfoot } \\
\text { Zona centrală mediană }\end{array}$ & $126.84 \pm 16.89^{\mathrm{a}}$ & $111.82 \pm 19.90^{\mathrm{a}}$ & $121.05 \pm 18.47$ \\
\hline $\begin{array}{c}\text { Lateral midfoot } \\
\text { Zona centrală laterală }\end{array}$ & $141.33 \pm 21.45$ & $147.52 \pm 38.98$ & $129.99 \pm 24.24$ \\
\hline $\begin{array}{c}\text { Medial forefoot } \\
\text { Antepicior median }\end{array}$ & $221.84 \pm 56.58$ & $250.26 \pm 63.29$ & $257.54 \pm 77.35$ \\
\hline $\begin{array}{c}\text { Middle forefoot } \\
\text { Antepicior central }\end{array}$ & $219.10 \pm 53.15^{\mathrm{b}}$ & $242.11 \pm 56.25$ & $269.30 \pm 59.76^{\mathrm{b}}$ \\
\hline $\begin{array}{c}\text { Lateral forefoot } \\
\text { Antepicior lateral }\end{array}$ & $148.35 \pm 50.67$ & $162.43 \pm 41.43$ & $176.00 \pm 44.27$ \\
\hline $\begin{array}{c}\text { Hallux } \\
\text { Haluce }\end{array}$ & $176.61 \pm 55.72$ & $211.21 \pm 78.39$ & $207.83 \pm 83.10$ \\
\hline $\begin{array}{c}\text { Lesser toes } \\
\text { Degete }\end{array}$ & $136.17 \pm 29.95$ & $121.74 \pm 33.28$ & $130.33 \pm 33.90$ \\
\hline
\end{tabular}

${ }^{a}$ Significant differences between Shoe 1 and Shoe 2 .

a Diferenţe semnificative între Modelul 1 şi Modelul 2.

${ }^{\mathrm{b}}$ Significant differences between Shoe 1 and Shoe 3.

${ }^{b}$ Diferenţe semnificative între Modelul 1 şi Modelul 3.

'Significant differences between Shoe 2 and Shoe 3.

'Diferenţe semnificative între Modelul 2 şi Modelul 3. 


\section{DISCUSSION}

The purpose of this study was to examine the effect of different shoe outsole shapes on plantar loading distribution during running. In total support of our hypotheses, the different shoe outsole shape truly had significant effects on plantar loading distribution during running.

Especially in the areas of rearfoot, medial forefoot, middle forefoot and lateral forefoot, the max pressure was increased gradually from shoe 1 to shoe 3 and in the areas of rearfoot, middle forefoot and lateral forefoot, the max force was increased gradually from shoe 1 to shoe 3 . The main differences of shoe 1 , shoe 2 and shoe 3 was the outsole shape, shoe 1 had a convexshaped outsole, while shoe 2 had a flat outsole, and the outsole of shoe 3 was concave in the midfoot area. The gradual increase of max pressure from shoe 1 to shoe 3 in the rearfoot area and forefoot areas, as well as the gradual increase of max force from shoe 1 to shoe 3 in the rearfoot area, middle and lateral forefoot area might be caused by the differences of the outsole shape for the reason that the convex-shaped outsole of shoe 1 makes the foot strike process easier. In this study, all the subjects were rearfoot strikers, that means that in the running process their heels land first and then the midfoot and last the forefoot. And the convex-shaped outsole was very proper for this pattern. There were also other striking patterns, which were midfoot striking and forefoot striking patterns. However, $75 \%-80 \%$ of endurance shod runners were rearfoot strikers $[23,24]$. In the midfoot area, shoe 1 presented the highest max force and the max pressure of shoe 1 in medial midfoot was also the highest. And this result could be linked with the former result. The convex-shaped outsole makes the midfoot area the main loading area and thus the loading of forefoot area and rearfoot are decreased. As a result, the plantar loading of shoe 1 was more even in the total foot.

Previous studies have indicated that repetitive mechanical loading on a bone was related to stress fractures [25] in conjunction with the bone failing to remodel quickly enough to adapt to the loadings [26]. Stress fractures were the most common overuse injuries, accounting for up to $50 \%$ of all

\section{DISCUTII}

Scopul acestui studiu a fost acela de a examina influenţa diferitelor forme de tălpi asupra distribuţiei presiunii plantare în timpul alergării. În concordanţă totală cu ipotezele noastre, formele diferite ale tălpilor pantofilor au avut, într-adevăr, efecte semnificative asupra distribuţiei presiunii plantare în timpul alergării.

În special, în zonele retropiciorului, antepiciorului median, antepiciorului central şi antepiciorului lateral, presiunea maximă a crescut treptat de la modelul 1 la modelul 3, iar în zonele retropiciorului, antepiciorului central şi antepiciorului lateral, forţa maximă a crescut treptat de la modelul 1 la modelul 3. Principala diferenţă a modelelor 1,2 şi 3 a fost forma tălpii: modelul 1 a avut o talpă exterioară convexă, modelul 2 a avut o talpă exterioară plată, iar talpa modelului 3 a fost concavă în zona mediană. Creşterea treptată a presiunii maxime de la modelul 1 la modelul 3 în zonele retropiciorului şi antepiciorului, precum şi creşterea treptată a forţei maxime de la modelul 1 la modelul 3 în zonele retropiciorului, antepiciorului central şi antepiciorului lateral ar putea fi cauzate de formele diferite, datorită faptului că talpa exterioară convexă a modelului 1 facilitează atingerea solului cu piciorul. În acest studiu, toţi subiecţii au atins solul cu retropiciorul, ceea ce înseamnă că, în procesul de alergare, contactul cu solul se face mai întâi cu piciorul, apoi cu zona centrală şi, în final, cu antepiciorul. Talpa exterioară convexă a fost foarte potrivită pentru acest tipar. Au existat, de asemenea, alte modele de atingere a solului, cu zona centrală şi cu antepiciorul. Cu toate acestea, $75 \%-80 \%$ dintre alergătorii de anduranţă ating solul cu retropiciorul $[23,24]$. În zona centrală, modelul 1 a prezentat cea mai mare forţă maximă, iar presiunea maximă din zona centrală mediană la modelul 1 a fost, de asemenea, cea mai mare. Acest rezultat ar putea avea o legătură cu rezultatul precedent. Talpa exterioară cu formă convexă face ca zona centrală să devină zona principală de încărcare şi, prin urmare, încărcarea zonelor antepiciorului şi retropiciorului scade. Ca urmare, încărcarea plantară la purtarea modelului 1 a fost mai uniformă pe toată suprafaţa piciorului.

Studiile anterioare au indicat faptul că presiunea mecanică repetată asupra unui os este corelată cu fracturile de stres [25], în conjuncţie cu incapacitatea osului de a nu se remodela suficient de repede pentru a se adapta la încărcare [26]. Fracturile de stres au fost cele mai frecvente leziuni datorate suprasolicitării, reprezentând până la 50\% din toate leziunile suferite de alergători [3-5]. 
injuries sustained by runners [3-5]. As shoe 1 presented the lowest loading in the forefoot and rearfoot area, we could deduce that running in shoe 1 might decrease the occurrence of stress fractures of metatarsal.

There were also limitations of this study. The first and most important issue was that the 3 pairs of shoes were not custom made and thus they had other differences besides the outsole structures. The 3 pairs of shoes could have different midsoles which were made by different materials with different properties. However, shoe midsole would affect the lower extremity kinematics and plantar loading during running $[19,27]$. And other differences such as the uppers, weight, forefoot, rearfoot and materials of outsoles and insoles might also affect the results. So we strongly suggest that in a future study, custom made shoes could be selected to make the testing shoes identical except for the outsole shape and examine the results. Another limitation of this study was that the running process was completed on a treadmill, while most recreational runners choose to run overground and running surface would affect the results. A study by Hong et al. suggested that treadmill running is associated with a lower magnitude of maximum plantar pressure and a lower maximum plantar force at the plantar areas [28]. Even in running overground, there were also differences caused by running surfaces for the reason that there were different surfaces such as natural grass, asphalt and so on. Tessutti et al. found that natural grass provokes lighter loads on the rearfoot and forefoot in recreational runners [29]. In this issue, a future study could also investigate the differences caused by outsole shape and running surfaces.

Future work in the area of distance running could pay more attention to the shape of shoe soles. Firstly, most individuals were shod runners and footwear was the main protection of the foot. In addition, the majority of the running shoes off the shelf were not custom made and mainly made by same or similar materials so the shape of shoes, especially the soles, could be a main effect on the cushion properties of running shoes. Furthermore, a future study could also discuss the effect of different outsole shapes on lower extremity kinematics and EMG to evaluate running shoes.
Întrucât modelul 1 a prezentat cea mai mică încărcare în zona antepiciorului şi retropiciorului, am putea deduce că purtarea modelului 1 la alergare ar putea reduce apariţia fracturilor de stres la nivelul metatarsienelor.

Au existat şi limitări în cadrul acestui studiu. Prima şi cea mai importantă problemă a fost că cele 3 perechi de pantofi nu au fost făcute la comandă şi, prin urmare, au avut şi alte diferenţe în afară de structura tălpii. Cele 3 perechi de pantofi pot avea tălpi intermediare diferite, realizate din materiale diferite, cu proprietăţi diferite. Cu toate acestea, talpa intermediară afectează cinematica extremităţilor inferioare şi încărcarea plantară în timpul alergării $[19,27]$. De asemenea, alte diferenţe, cum ar fi feţele de încălţăminte, greutatea, antepiciorul, retropiciorul şi materialele din care sunt realizate tălpile exterioare şi branţurile, ar putea afecta rezultatele. De aceea, sugerăm ca într-un studiu viitor să se aleagă pantofi personalizaţi pentru testare, identici cu excepţia formei tălpii exterioare şi să se analizeze rezultatele. $\mathrm{O}$ altă limitare a acestui studiu a fost faptul că procesul de alergare s-a desfăşurat pe o bandă de alergare, în timp ce majoritatea alergătorilor de agrement aleargă pe sol, iar suprafaţa de alergare poate afecta rezultatele. Un studiu efectuat de Hong şi colab. sugerează că banda de alergare este asociată cu o magnitudine mai mică a presiunii plantare maxime şi o forţă plantară maximă mai scăzută în regiunile plantare [28]. Chiar şi în cazul alergării pe sol au existat diferenţe cauzate de suprafeţele de alergare pentru motivul că au existat suprafeţe diferite, cum ar fi iarba naturală, asfaltul etc. Tessutti şi colab. au constatat că iarba naturală reduce încărcătura asupra retropiciorului şi antepiciorului la alergătorii de agrement [29]. Cu privire la această problemă, un studiu ulterior ar putea investiga, de asemenea, diferenţele cauzate de forma tălpii exterioare şi de suprafeţele de alergare.

Activităţile de lucru viitoare în domeniul alergării ar putea să acorde mai multă atenţie formei tălpilor exterioare. În primul rând, majoritatea alergătorilor poartă pantofi, iar încălţămintea constituie protecţia principală a piciorului. În plus, majoritatea pantofilor de alergat din comerţ nu sunt făcuţi la comandă şi sunt realizaţi în principal din materiale identice sau similare, astfel încât forma pantofilor, în special a tălpilor, ar putea avea o influenţă semnificativă asupra proprietăţilor de amortizare a pantofilor de alergat. Mai mult, studii ulterioare ar putea discuta, de asemenea, influenţa diferitelor forme ale tălpii exterioare asupra cinematicii extremităţilor inferioare şi activităţii electrice musculare(EMG) pentrua evalua pantofii de alergat. 


\section{CONCLUSIONS}

The results of this study demonstrated that different shoe outsole shapes would affect plantar loading significantly during running. In particular, the convex-shaped outsole structure of shoe 1 presented the lowest loadings in the forefoot and rearfoot areas which could lead to the conclusion that shoe 1 was very proper for use in jogging by rearfoot strikers. And as the outsole changed from convex-shaped to flat to concave-shaped, the max pressure in forefoot and rearfoot areas was gradually increased. The max force also increased in rearfoot and medial and middle forefoot area from shoe 1 to shoe 3 . The results of the present study indicate that different shoe outsole shapes would affect plantar loading significantly and therefore runners should take the outsole structures into consideration when choosing the most proper shoes for training or competition.

\section{CONCLUZII}

Rezultatele acestui studiu au demonstrat că diferitele forme ale tălpilor pantofilor pot afecta în mod semnificativ presiunea plantară în timpul alergării. În particular, structura convexă a tălpii modelului 1 a prezentat cele mai reduse presiuni din zonele antepiciorului şi retropiciorului, ceea ce a dus la concluzia că modelul 1 a fost foarte potrivit pentru alergătorii care ating solul cu retropiciorul în alergare. La trecerea de la talpa cu formă convexă, la cea plată, apoi la cea concavă, presiunea maximă în zonele retropiciorului şi antepiciorului a crescut treptat. Forţa maximă a crescut, de asemenea, în zonele retropiciorului şi antepiciorului median şi central de la modelul 1 la modelul 3. Rezultatele prezentului studiu indică faptul că diferite forme ale tălpilor afectează în mod semnificativ presiunea plantară, prin urmare, alergătorii trebuie să ia structurile tălpilor în considerare atunci când aleg încălţămintea adecvată pentru antrenament sau competiţie.

\section{REFERENCES}

1. Taunton, J.E., Ryan, M.B., Clement, D.B., McKenzie, D.C., Lloyd-Smith, D.R., Zumbo, B.D., A retrospective case-control analysis of 2002 running injuries, BrJ Sports Med, 2002, 26, 95-101.

2. Murphy, D.F., Connolly, D.A.J., Beynnon, B.D., Risk factors for lower extremity injury: a review of literature, BrJ Sports Med, 2003, 37, 13-29.

3. Milner, C.E., Ferber, R., Pollard, C.D., Hamill, J., Davis, I.S., Biomechanical factors associated with tibial stress fracture in female runners, Med Sci Sports Exerc, 2006, 38, 2, 323-8.

4. James, S., Bates, B., Ostering, L., Injuries to runners, Am J Sports Med, 1978, 6, 40-50.

5. Kowal, D., Nature and causes of injuries in women resulting from an endurance training program, Am J Sports Med, 1980, 8, 265-9.

6. McBryde, A., Stress fractures in runners, Clin Sports Med, 1985, 4, 737-52.

7. Taimela, S., Kujala, U.M., Osterman, K., Intrinsic risk factors and athletic injuries, Sports Med, 1990, 9, 205-15.

8. Wen, D., Pugger, J.C., Schmalzride, T.P., Lower extremity alignment and risk of overuse injuries in runners, Med Sci Sports Exerc, 1997, 29, 1291-8.

9. Jarvinen, M., Lower leg overuse injuries in athletes, Knee Surg Sports Traumatol Arthrosc, 1993, 1, 126-30.

10. McKenzie, D.C., Clement, D.B., Taunton, J.E., Running shoes orthotics, and injuries, Sports Med, 1985, 2, 334-47.

11. Clinghan, R., Arnold, G.P., Drew, T.S., Cochrane, L.A., Abboud, R.J., Do you get value for money when you buy an expensive pair of running shoes?, BrJ Sports Med, 2008, 42, 189-93.

12. Dixon, S., Collop, A.C., Batt, M.E., Surface effects on ground reaction forces and lower extremity kinematics in running, Med SciSports Exerc, 2000, 32, 1919-26.

13. Nigg, B.M., Stefanyshyn, D.J., Cole, G.K., Stergiou, P., Miller-Young, J., The effect of material characteristics of shoe soles on muscle activation and energy aspects during running, J Biomech, 2003, 36, 569-75.

14. Buczek, F.L., Cavanagh, P.R., Stance phase knee and ankle kinematics and kinetics during level and downhill running, 
Med SciSports Exerc, 1990, 22, 669-77.

15. Eils, E., Streyl, M., Linnenbecker, S., Thorwesten, L., Volker, K., Rosenbaum, D., Characteristic plantar pressure distribution patterns during soccer-specific movements, Am J Sports Med, 2004, 32, 1, 140-5.

16. Queen, R., Haynes, B., Hardaker, W., Garrett, W., Forefoot loading during 3 athletic tasks, Am J Sports Med, 2007, 25, 4, 630-6.

17. Wong, P.L., Chamari, K., Mao, D.W., Wisloff, U., Higher plantar pressure on the medial side in four soccer-related movements, BrJSports Med, 2007, 41, 93-100.

18. Dinato, R.C., Ribeiro, A.P., Butugan, M.K., Pereira, I.L.R., Onodera, A.N., Sacco, I.C.N., Biomechanical variables and perception of comfort in running shoes with different cushioning technologies, J Sci Med Sport, 2014, 18, 1, 93-97.

19. Ly, Q.H., Alaoui, A., Erlicher, S., Baly, L., Towards a footwear design tool: Influence of shoe midsole properties and ground stiffness on the impact force during running, J Biomech, 2010, 43, 2, 310-317.

20. Murphy, D.F., Beynnon, B.D., Michelson, J.D., Vacek, P.M., Efficacy of plantar loading parameters during gait in terms of reliability, variability, effect of gender and relationship between contact area and plantar pressure, Foot Ankle Int, 2005, 26, 2, 171-9.

21. Putti, A.B., Arnold, G.P., Cochrane, L., Abboud, R.J., The Pedar in-shoe system: repeatability and normal pressure values, Gait Posture, 2007, 25, 401-5.

22. Hsiao, H., Guan, J., Weatherly, M., Accuracy and precision of two in-shoe pressure measurement systems, Ergonomics, 2002, 45, 537-55.

23. Kerr, B.A., Beauchamp, L., Fisher, V., Neil, R., Footstrike patterns in distance running, in: Nigg, B., Kerr, B., eds., Biomechanical aspects of sports shoes and playing surfaces, Calgary, University of Calgary, 1983, 135-141.

24. Hasegawa, H., Yamauchi, T., Kraemer, W.J., Foot strike patterns of runners at $15-\mathrm{km}$ point during an elite-level half marathon, JStrength Cond Res, 2007, 21, 888-893.

25. Bennell, K.L., Brukner, P.D., Epidemiology and site specificity of stress fractures, Clin Sports Med, 1997, 16, 2, 179-96.

26. Bennell, K., Crossley, K., Jayarajan, J., Walton, E., Warden, S., Kiss, S.Z., Wrigley, T., Ground reaction forces and bone parameters in females with tibial stress fracture, Med Sci Sports Exerc, 2004, 36, 3, 397-404.

27. Chambon, N., Delattre, N., Guéguen, N., Berton, E., Rao, G., Is midsole thickness a key parameter for the running pattern?, Gait Posture, 2014, 40, 1, 58-63.

28. Hong, Y., Wang, L., Li, J.X., Zhou, J.H., Comparison of plantar loads during treadmill and overground running, J Sci Med Sport, 2012, 15, 554-560.

29. Tessutti, V., Trombini-Souza, F., Ribeiro, A.P., Nunes, A.L., Sacco, I.C.N., In-shoe plantar pressure distribution during running on natural grass and asphalt in recreational runners, J Sci Med Sport, 2010, 13, 151-155.

Article received/Data primirii articolului: 09.09.2015

Accepted/Acceptat la data: 24.02.2016 